\title{
Properties of a Small Bacteriophage and the Action of some Compounds on it
}

\author{
By R. F. N. MILLS \\ Virology Section, Bacteriology Division, Research Department, \\ Boots Pure Drug Co. Ltd., Nottingham
}

SUMMARY: Phage S13, a small phage active against a strain of Escherichia coli, had a latent period of $20 \mathrm{~min}$. on this host. Intracellular phage multiplication was detected only toward the end of the latent period. Photo-reactivation of ultraviolet irradiated phage occurred, but the inactivated phage did not kill its host. More than 1600 compounds were tested for ability to prevent growth of phage S13 on E. coli at concentrations allowing growth of the bacterium, but only thirteen were active. Seven of these compounds were examined further; none affected free S13 phage or the adsorption of S13 phage to its host. The only compound investigated in detail, 4: : 4-bis-(2-dihydroglyoxalinyl) stilbene dihydrochloride, inhibited both early and late, but probably not intermediate, stages in the intracellular development of $\mathbf{S 1 3}$ phage. This was different from the action of this compound on $\mathrm{T} 1$ phage. No relationship was found between structure and action against phage, nor between compounds active against S13 phage and those active against larger phages.

As part of an investigation into virus chemotherapy, S13 phage of Shigella paradysenteriae ( $S$. flexneri) $\mathbf{Y} 6 \mathbf{R}$ was used as a representative of the smallest viruses. Elford \& Andrewes (1932) by ultrafiltration estimated its diameter to be 8-12 $\mathrm{m} \mu$., while Elford (1936) by a centrifugation method found it to be 15-17 $\mathrm{m} \mu$. i.e. it was of the same order of size as the viruses of poliomyelitis and foot and mouth disease. Because of its small size $S 13$ phage might differ from larger phages in some of its properties. This paper reports studies on these properties, including the action of certain compounds on this phage, and a comparison of the activity of one of these compounds on S13 with its activity on T1 phage of Escherichia coli.

\section{EXPERIMENTAL}

S13 phage, and a strain of Escherichia coli against which $\mathrm{S} 13$ phage was active, were obtained through the courtesy of Dr C. H. Andrewes, F.R.S. In this paper the bacterium will be termed $E$. coli CHA.

Strains. Stock S13 phage was prepared by the method of Swanstrom \& Adams (1951). Best results were obtained by concentrating a $24 \mathrm{hr}$. broth culture of Escherichia coli CHA tenfold by centrifugation and using the concentrate for sowing the plates. The lysate was filtered through a Gradocol membrane of porosity $0 \cdot 9 \mu$. The final titre was $4 \times 10^{10}$ particles $/ \mathrm{ml}$.

T1 phage was prepared by sowing a $2 \mathrm{hr}$. Lab-Lemco broth culture of Escherichia coli CHA with $10^{4}$ particles of $\mathrm{T} 1$ phage previously obtained by lysis of $E$. coli B, incubating at $37^{\circ}$ for $6 \mathrm{hr}$., then filtering through a Gradocol membrane of porosity $0.9 \mu$. The final titre was $3 \times 10^{9}$ particles $/ \mathrm{ml}$. T 1 phage 
prepared from $E$. coli $\mathrm{B}$ gave 100 times more plaques when plated on $E$. coli B than when plated on $E$. coli CHA. The phage obtained by lysis of $E$. coli CHA gave the same titre on both bacterial strains. The variation appears to be a phenotypic one similar to that described by Bertani \& Weigle (1953).

Escherichia coli CHA grew (slowly) on a defined medium which contained lactic acid and ammonia as sole sources of carbon and nitrogen. It was sensitive to T1, T3 and T7 but resistant to T2, T4, T5 and T6 phages of E. coli B.

Media. Lab-Lemco broth was used as liquid medium and nutrient (tryptic digest) agar as solid medium.

Titration of phage. For one-step growth experiments: to $1 \mathrm{ml}$. phage suspension in a test tube, $1 \mathrm{ml}$. of a $24 \mathrm{hr}$. culture of Escherichia coli CHA and $3 \mathrm{ml}$. nutrient agar were added. After the contents had been mixed, the tubes were sloped and incubated at $37^{\circ}$ for $4 \mathrm{hr}$. before reading. In all other experiments the mixture was poured on $15 \mathrm{ml}$. agar bases instead of sloping, and the plates incubated for $24 \mathrm{hr}$. at $37^{\circ}$ before reading. The shorter period of incubation was necessary after sloping, as after $\mathbf{2 4} \mathrm{hr}$. plaques were too large for convenient numbers to be counted in tubes.

\section{RESULTS}

Stability of S13 phage. S 13 phage was stable in Ringer's solution at $37^{\circ}$ for at least $30 \mathrm{~min}$. and at $5^{\circ}$ for at least 6 months; at $60^{\circ}$ the titre fell from $3 \times 10^{6}$ particles $/ \mathrm{ml}$. to $4 \times 10^{3}$ particles $/ \mathrm{ml}$. in $30 \mathrm{~min}$. In $\mathrm{M} / \mathbf{1 5}$ phosphate + citrate buffer at $37^{\circ}, \mathrm{S} 13$ phage was stable at $\mathrm{pH} 8$ for at least $1 \mathrm{hr}$.; at $\mathrm{pH} 5$ the titre fell from $1 \times 10^{6} / \mathrm{ml}$. to $1 \times 10^{5}$ particles $/ \mathrm{ml}$. in $1 \mathrm{hr}$. $\mathrm{pH}$ values outside the range 5-8 were not investigated.

Latent period (Fig. 1). The method of Dickinson \& Codd (1952) was used. To obtain good absorption a $2 \mathrm{hr}$. culture of Escherichia coli CHA was suspended in Ringer's solution, incubated at $37^{\circ}$ for $5 \mathrm{~min}$. only, and $\mathrm{S} 13$ phage added to give $2 \times 10^{8}$ host cells and $10^{8}$ phage particles $/ \mathrm{ml}$. The mixture was incubated $10 \mathrm{~min}$. before dilution into broth. The latent period was about $20 \mathrm{~min}$.

No increase in the titre of S13 phage was found when KCN (final concentration 0.02 $\mathrm{m}$; Rountree, 1951) was added at any time during the first half of the latent period (Fig. 1). Attempts to break open the bacterial cell at earlier times by the method of Rountree (1951) were unsuccessful.

Effect of ultraviolet radiation on $\mathrm{S} 13$ phage. S 13 phage $\left(4 \times 10^{9}\right.$ particles $/ \mathrm{ml}$.) in broth was irradiated with a 15 W. 18 in. British Thomson-Houston germicidal lamp (which gave $99 \%$ of its energy at a wavelength of 2537 A.) at a distance of $37.5 \mathrm{~cm}$. An exposure of $60 \mathrm{~min}$. (the dose usually given) was required to decrease the titre one hundredfold. The irradiated phage had a significantly higher titre when absorbed on a $2 \mathrm{hr}$. culture of Escherichia coli CHA for 5 min. in daylight before counting than when counted immediately (Table 1). The effect increased with decreasing phage concentration over a fourfold range, so that it was not due to multiplicity reactivation. No increase occurred on dilution in absence of $E$. coli CHA. No work was done in absence of light but it seems reasonable to attribute the observed effect to photo-reactivation. 


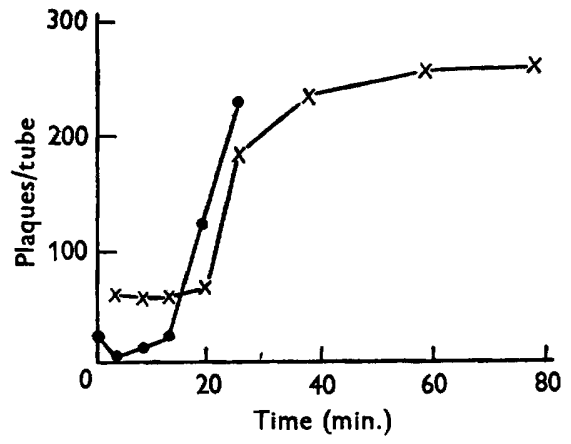

Fig. 1.

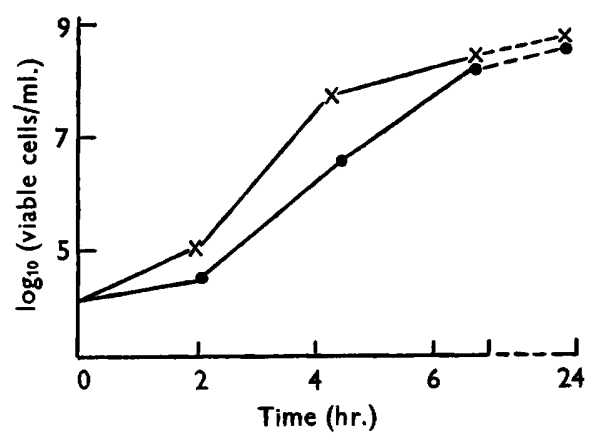

Fig. 2.

Fig. 1. Premature liberation of intracellular S13 phage by addition of $0.02 \mathrm{M}-\mathrm{KCN}$ at various times. $x-\times$, latent period in absence of cyanide; -0 , phage yield when cyanide added at various times.

Fig. 2. The action of compound no. $347(20 \mu \mathrm{g} . / \mathrm{ml}$.) on the growth of Escherichia coli CHA. $x \longrightarrow x$, compound no. 347 absent; , compound no. 347 present.
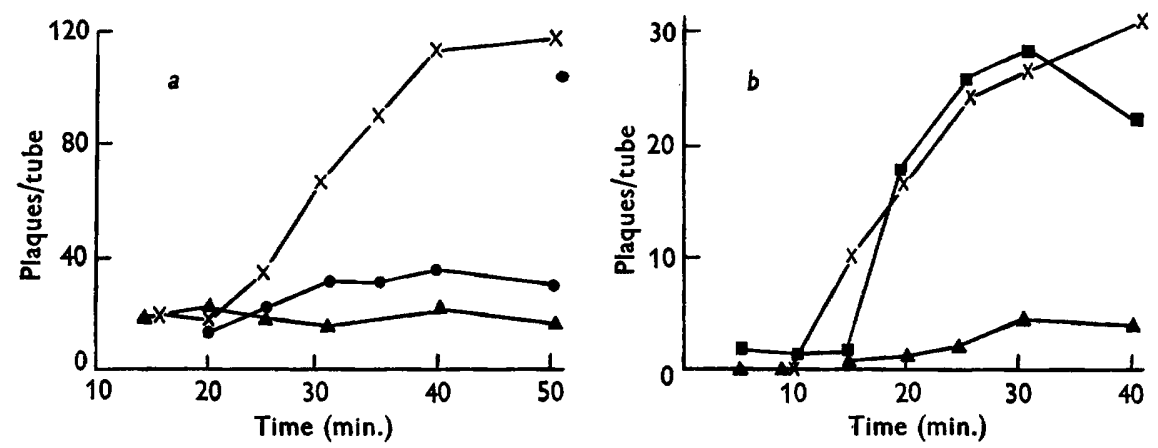

Fig. 3. The effect of compound no. $347(20 \mu \mathrm{g} . / \mathrm{ml}$.) on the latent periods on broth of $(a) \mathrm{S} 13$ phage, (b) T1 phage on Escherichia coli CHA. $\times-\times$, compound no. 347 absent; $\Delta-\Delta$, compound no. 347 present throughout; $\square \longrightarrow$, compound no. 347 added at 3 min.; $\longrightarrow$, compound no. 347 added at 20 min.

Table 1. Reactivation of ultraviolet-inactivated $\mathrm{S} 13$ phage in the presence of Escherichia coli $\mathbf{C H A}$

\begin{tabular}{|c|c|c|}
\hline Treatment & $\begin{array}{c}\text { Host } \\
\text { presence }\end{array}$ & $\begin{array}{l}\text { Phage count } \\
\text { (particles/ml.) }\end{array}$ \\
\hline Unirradiated & - & $1.6 \times 10^{9}$ \\
\hline Irradiated & - & $1.6 \times 10^{7}$ \\
\hline Irradiated, diluted* 1 : 2 & + & $1.2 \times 10^{7}$ \\
\hline Irradiated, diluted $1: 4$ & + & $7 \cdot 3 \times 10^{6}$ \\
\hline Irradiated, diluted $1: 8$ & + & $\begin{array}{c}4.4 \times 10^{6} \\
\text { Host count } \\
(\text { no. } / \mathrm{ml} .)\end{array}$ \\
\hline Host + brc & - & $1.4 \times 10^{7}$ \\
\hline Host + unirradiated phage & - & $8 \times 10^{4}$ \\
\hline
\end{tabular}

* Dilutions were in broth. The first dilution was due to mixing equal volumes of phage and host. Phage and host were incubated together for $5 \mathrm{~min}$. before counting. 
In the course of this work it was noted that though infection of Escherichia coli CHA with normal S13 phage decreased the viable bacterial count, infection with ultraviolet (u.v.)-inactivated S13 phage failed to do so (Table 2). Studies on antiserum neutralization by u.v.-inactivated $S 13$ phage failed to

Table 2. Effect of ultraviolet-inactivated $\mathrm{S} 13$ and $\mathrm{T} 1$ phages on the viability of Escherichia coli $\boldsymbol{C H} \boldsymbol{A}$

Equal volumes of host and phage were incubated together for $5 \mathrm{~min}$. before host counts were made.

$\begin{array}{lcr} & \text { S13 phage } & \text { T1 phage } \\ & \text { Phage count (particles/ml.) } \\ \text { Before irradiation } & 4 \times 10^{9} & 2.5 \times 10^{9} \\ \text { After irradiation } & 5 \cdot 6 \times 10^{6} & 5.8 \times 10^{6}\end{array}$

Host + broth

Host + unirradiated phage
Host + irradiated phage
Host count (no. $/ \mathrm{ml}$.)

$\begin{array}{ll}1.6 \times 10^{8} & 9.0 \times 10^{6} \\ 3.6 \times 10^{7} & 1.4 \times 10^{4} \\ 1.7 \times 10^{8} & 1.5 \times 10^{4}\end{array}$

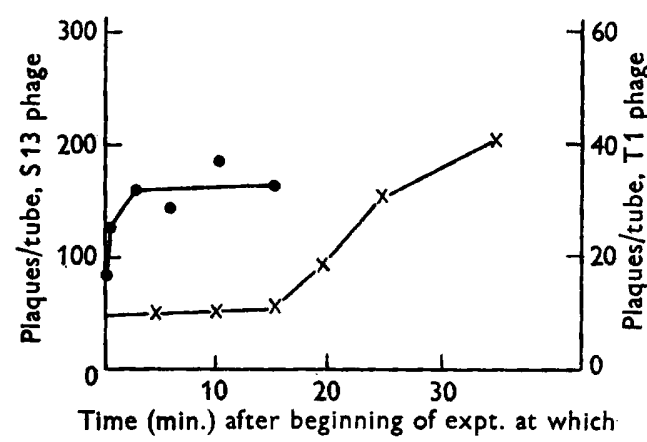

no. 347 was added to the phage and host mixture

Fig. 4.

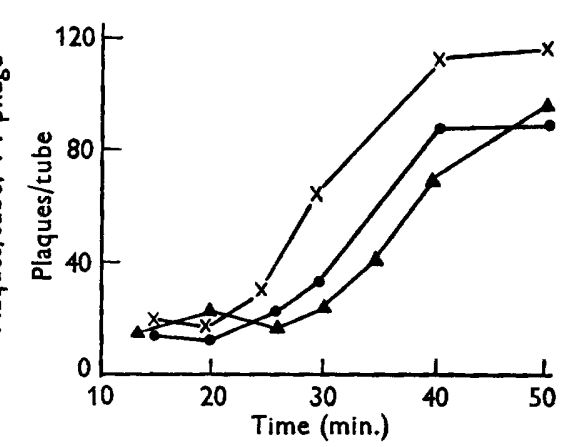

Fig. 5.

Fig. 4. Effect of compound no. $347(20 \mu \mathrm{g} . / \mathrm{ml}$.) on the yields of S13 and $\mathrm{T} 1$ phages from Escherichia coli CHA when added at different times during their latent periods.

T1 phage; $\times-\times, S 13$ phage. Tubes were 'sloped' at $60 \mathrm{~min}$.

Fig. 5. The effect of diluting out compound no. $347(20 \mu \mathrm{g} . / \mathrm{ml}$.) on the latent period of S13 phage on Escherichia coli CHA. $\times-\times$, compound no. 347 absent; $\Delta-\Delta$, compound no. 347 initially present, diluted out at 15 min.; - , compound no. 347 added at $5 \mathrm{~min}$., diluted out at $15 \mathrm{~min}$.

show whether it was adsorbed on $\boldsymbol{E}$. coli CHA, but as reactivation occurred only in presence of $\boldsymbol{E}$. coli CHA it appears probable that adsorption did take place. It was confirmed (Table 2) that u.v.-inactivated $\mathrm{T} 1$ phage killed E. coli CHA.

\section{Action of various compounds on $\mathrm{S} 13$ phage}

A preliminary test of each compound against $S 13$ phage was made by a cupplate diffusion method using a $1 \%(\mathrm{w} / \mathrm{v})$ neutral aqueous solution or suspension of the compound in a single cup. Those compounds which gave an appreciable zone of phage inhibition were retested by the serial dilution method of Chantrill, Coulthard, Dickinson, Inkley, Morris \& Pyle (1952), using five-fold 
serial dilutions. Some of the compounds found active in this test were examined in greater detail by the method of Mills (1953).

Of more than 1600 compounds screened against $S 13$ phage only thirteen were active by the serial dilution method (Table 3), though many showed appreciable activity in the cup-plate test. No reason was found for this

Table 3. Compounds which prevented the growth of $\mathrm{S} 13$ phage on Escherichia coli $\boldsymbol{C H A}$

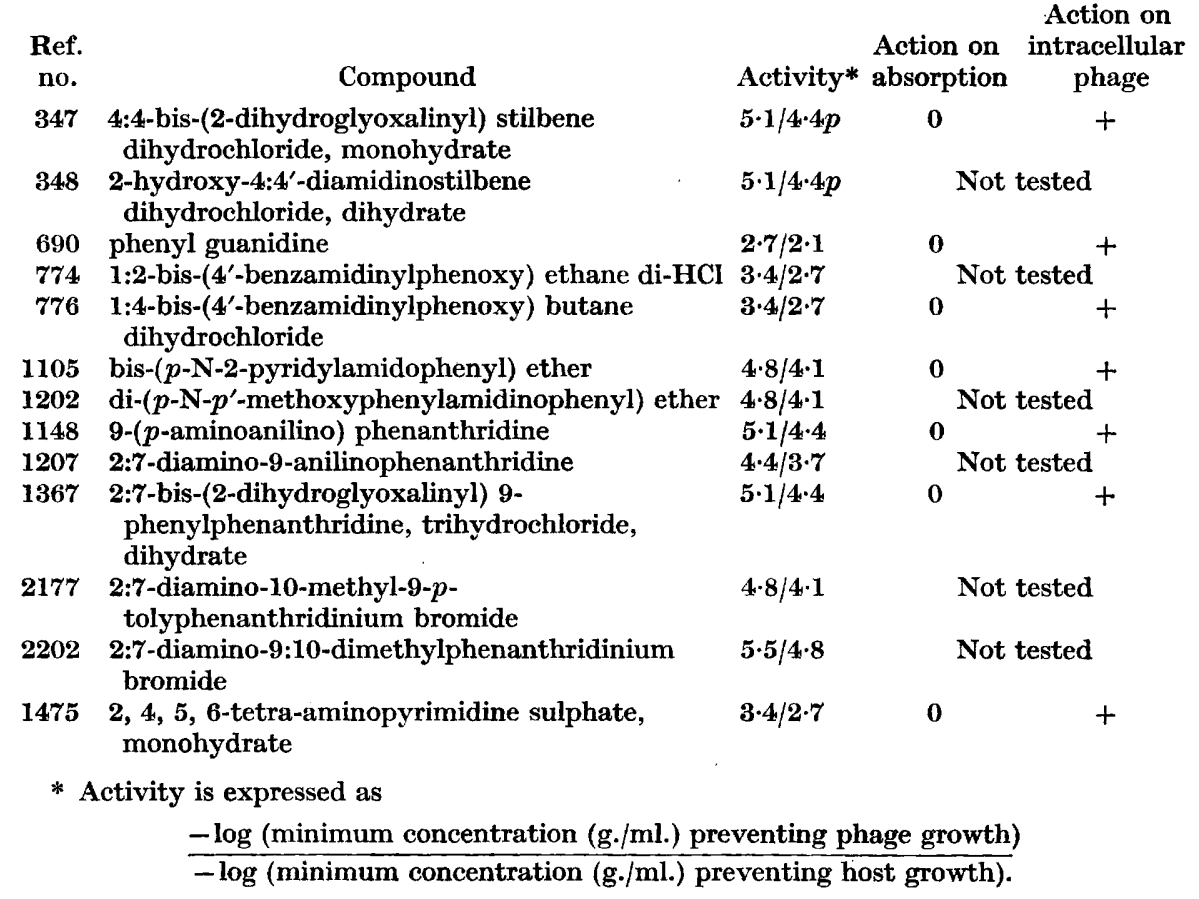

difference in response. No compound affected the titre of $\mathrm{S} 13$ phage at its active concentration, and none of seven compounds tested prevented adsorption of S13 phage on Escherichia coli CHA. All compounds tested except one, no. 347, 4: 4-bis-(2-dihydroglyoxalinyl) stilbene dihydrochloride, decreased host growth too much at the active concentration for more detailed work to be of value.

\section{Action of compound $\mathbf{3 4 7}$}

In a one-step growth experiment compound 347 prevented phage multiplication at $20 \mu \mathrm{g} . / \mathrm{ml}$. and caused little phage loss (Fig. $3 a$ ). This concentration was used for the rest of the work reported here. Compound 347 did not diminish the titre of free S13 phage (Table 4), nor did it prevent a burst when present during absorption if, after absorption, it was diluted well below the limit of activity (Table 5). It slightly retarded the growth of Escherichia coli CHA as measured by plate colony counts (Fig. 2).

Action on intracellular $\mathrm{S} 13$ phage. Compound 347 was added at various times 
during the latent period to samples of the phage + host system, and left till the burst had ended. There was no phage multiplication when compound 347 was added during the first $15 \mathrm{~min}$. When added after $15 \mathrm{~min}$., phage yield increased the more the later compound 347 was added (Fig. 4). When added at 20 min. compound 347 did not increase the latent period (Fig. $3 a$ ).

Table 4. Action of compound 347 on free $\mathrm{S} 13$ and $\mathrm{T} 1$ phages in broth

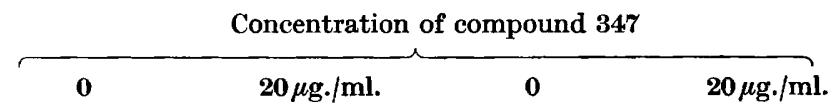

\begin{tabular}{|c|c|c|c|}
\hline Time & S13 phage (phage count & $\left.\times 10^{-4}\right)$ & T1 phage (phage count $1.25 \times 10^{-5}$ ) \\
\hline 0 & 47,40 & 1, 39 & 22,17 \\
\hline $\mathbf{1}$ & 28,22 & , 49 & 23,21 \\
\hline
\end{tabular}

Table 5. Action of compound 347 on the adsorption of $\mathrm{S} 13$ and $\mathrm{T} 1$ phages on Escherichia coli $\mathbf{C H A}$

Concentration of compound 347 was $20 \mu \mathrm{g} . / \mathrm{ml}$.

\begin{tabular}{|c|c|c|c|c|c|}
\hline \multirow{2}{*}{\multicolumn{2}{|c|}{$\begin{array}{c}\text { Presence }(+) \text { or absence }(-) \\
\text { of compound } 347\end{array}$}} & & & \multicolumn{2}{|c|}{$\begin{array}{l}\text { T1 phage*, } \\
\text { plaques observed }\end{array}$} \\
\hline & & \multirow{2}{*}{\multicolumn{2}{|c|}{$\begin{array}{c}\text { S13 phage, } \\
\text { plaques/tube at }\end{array}$}} & \multirow{3}{*}{$\begin{array}{l}\text { Diluted } \\
1 / 10 \text { at } \\
7 \mathrm{~min} .\end{array}$} & \multirow{3}{*}{$\begin{array}{l}\text { Diluted } \\
1 / 100 \text { at } \\
60 \mathrm{~min} .\end{array}$} \\
\hline During & After & & & & \\
\hline adsorption & dilution & $10 \mathrm{~min}$. & $60 \mathrm{~min}$. & & \\
\hline- & - & $30,29,38$ & $133,183,158$ & $26,23,23$ & $80,79,93$ \\
\hline- & + & $28,25,15$ & $\begin{array}{lll}15, & 6, & 6\end{array}$ & $27,26,29$ & $39,36,29$ \\
\hline+ & - & $29,25,31$ & $135,155,180$ & $29,23,22$ & $71,77,84$ \\
\hline+ & + & $23,19,27$ & $15, \quad 6, \quad 15$ & $23,28,29$ & $3,5,2$ \\
\hline
\end{tabular}

* In the experiment on $\mathrm{T} 1$ phage, the phage was diluted ten-fold immediately before counting at $7 \mathrm{~min}$. and 100 -fold immediately before counting at $60 \mathrm{~min}$. The figures given are the counts observed.

Effect of diluting out. When compound 347 was present initially and was diluted out at $15 \mathrm{~min}$., the latent period was lengthened by about $10 \mathrm{~min}$. (Fig. 5). The results of this and the preceding experiments suggested that compound $\mathbf{3 4 7}$ was acting at the beginning and at the end of the latent period. To determine whether it was also acting at intermediate stages it was added at 5 min., diluted out at $15 \mathrm{~min}$., and the latent period measured. The results (Fig. 5) were equivocal but suggested that any action it had on intermediate stages could only be slight.

\section{Effect of the active compounds on $\mathrm{T} 1$ coliphage}

For comparison with the results reported above, some experiments were made on $\mathbf{T} 1$ coliphage grown on Escherichia coli CHA, using the same methods of testing. Eleven of the thirteen compounds active against $\mathrm{S} 13$ phage were tested by the serial dilution method against $\mathrm{T} 1$ phage; only three were active, including compound 347 , and a few experiments on its mode of action were 
made. It prevented multiplication of T 1 phage on $E$. coli CHA at $0 \cdot 3 \mu \mathrm{g} . / \mathrm{ml}$., compared with $8 \mu \mathrm{g} . / \mathrm{ml}$. for S 13 phage. At $20 \mu \mathrm{g} . / \mathrm{ml}$. it had no action on free T1 phage (Table 5), nor on the absorption of T1 phage on to $E$. coli CHA. It had little effect on the yield of T 1 phage when added at $20 \mu \mathrm{g} . / \mathrm{ml}$. at $3 \mathrm{~min}$. or more after the start of the latent period (Figs. $3 b$ and 4 ).

\section{DISCUSSION}

The only unusual property observed of the $\mathbf{S} 13$ phage + Escherichia coli CHA system was the failure of $\mathbf{S} 13$ phage after inactivation by ultraviolet irradiation to kill its host. In this it differed from T2 (Dulbecco, 1952) and T1 coliphages. On the other hand, S13 phage, in its response to the compounds tested for inhibitory activity against it, differed considerably from certain larger phages. Thus proflavine was inactive against $\mathrm{S} 13$ phage though active against $\mathrm{T} 2$ phage (Foster, 1948), $\mathrm{Pb}$ phage of Pseudomonas aeruginosa (Dickinson, 1948) and staphylococcus phage K (Hotchin, 1951): several phenanthridines active against $\mathrm{Pb}$ phage (Dickinson, Chantrill, Inkley \& Thompson, 1953) were inactive against $S 13$ phage, while two (nos. 1148 and 1207) were active against $\mathrm{S} 13$ phage but not $\mathrm{Pb}$ phage. Of the eleven compounds active against $\mathrm{S} 13$ phage and tested against $\mathrm{T} 1$ phage, only three (nos. 347, 1367 and 2202) were active against the latter. While there was no relationship between activity against $\mathrm{S} 13$ phage and against larger phages, equally it was clear from consideration of the active compounds (Table 3 ) and certain inactive ones (not listed here) that there was no relationship between the structure of a compound and its activity against S13 phage.

The only compound (no. 347) whose action on S13 phage was studied in detail had previously been reported to be active against $\mathrm{Pb}$ phage of $\boldsymbol{P}$ seudomonas aeruginosa (Dickinson \& Codd, 1952). Its action on $\mathrm{T} 1$ phage resembled that of the phenanthridine no. 1367 on $\mathrm{Pb}$ phage (Mills, 1953; Table 3). Its action on S13 phage appeared to combine such an action with one similar to that of proflavine on T2 phage (Foster, 1948).

The author wishes to thank Dr Löis Dickinson for her advice and criticism, Mr C. E. Coulthard for his interest and encouragement and Miss Ann Wheater for technical assistance. The compounds tested were supplied by the Chemistry Division of the Research Department, Boots Pure Drug Co. Ltd.

\section{REFERENCES}

Bertan, B. \& Weigle, J. J. (1953). Host controlled variation in bacterial viruses. J. Bact. 65, 113.

Chantriml, B. H., Coulthard, C. E., Dickinson, L., Inkley, G. W., Morris, W. \& PyLE, A. H. J. (1952). The action of plant extracts on a bacteriophage of Pseudomonas pyocyanea and on influenza A virus. J. gen. Microbiol. 6, 74.

Dickrnson, L. (1948). The bacteriophages of Pseudomonas pyocyanea. (1) The effect of various substances on their development. J. gen. Microbiol. 2, 154.

Dickinson, L., Chantrill, B. H., Inkley, G. W. \& Thompson, M. J. (1953). The antiviral action of phenanthridinium compounds. Brit. J. Pharmacol. 8, 139. 
Dickinson, L. \& Codd, S. (1952). The bacteriophages of Pseudomonas pyocyanea. (2) Bacteriophage reproduction in an iridescent strain. J. gen. Microbiol. 6, 1. Dulbecco, R. (1952). A critical test of the recombination theory of multiplicity reactivation. J. Bact. $63,199$.

Elford, W. J. (1936). Centrifugation studies: (1) Critical examination of a new method as applied to the sedimentation of bacteria, bacteriophages and proteins. Brit. J. exp. Path. 17, 399.

Elford, W. J. \& ANDrewes, C. H. (1932). Sizes of different bacteriophages. Brit. J. exp. Path. 13, 446.

Foster, R. A. C. (1948). An analysis of the action of proflavine on bacteriophage growth. J. Bact. 56, 795 .

Hotchin, J. E. (1951). Influence of acridines on interaction of Staphylococcus aureus and staphylococcus phage K. J. gen. Microbiol. 5, 609.

Mruss, R. F. N. (1953). The action of $2:$ 7-bis-(2'-dihydroglyoxalinyl)-9-phenylphenanthridine on a bacteriophage of Pseudomonas pyocyanea. Brit. J. Pharmacol. 8, 143.

Rountree, P. M. (1951). A complement-fixing antigen of Bact. coli bacteriophage T5: its behaviour during virus growth. Brit. J. exp. Path. 32, 341.

Swanstrom, M. \& Adams, M. H. (1951). Agar layer method for production of high titre phage stocks. Proc. Soc. exp. Biol., N.Y. 78, 372. 